\title{
Türkiye ve Seçilmiş Ülkelerde Ar-Ge Faaliyetlerine Yönelik Uygulanan Vergi Teşviklerinin Karşılaştırılması ${ }^{1}$
}

\author{
Hüseyin KUTBAY* $\quad$ Ersan ÖZ ${ }^{* *}$
}

\begin{abstract}
$\ddot{O} Z$
Sosyal getirisi özel getirisinden daha fazla gerçekleşen Ar-Ge yatırımları konusunda firmalar çekimser kalmaktadırlar. Firmaların çekingen davranmasının önüne geçmek için ise ülkeler çeşitli teşvik araçlarına başvurmaktadırlar. Ar-Ge yatırımları büyük sermaye ve uzun bir süreç gerektirdiği için birçok firma tarafindan bu alana yatırım yapılmak istenmemekte olup Ar-Ge teşviklerinin önemi burada devreye girmektedir. Bu çalışmada, Türkiye ve seçilmiş ülkelerde Ar-Ge faaliyetlerine yönelik sağlanan vergi teşviklerini çeşitlilik, kapsam ve oran yönünden karşılaştırılması amaçlanmış olup Türkiye'de Ar-Ge faaliyetlerine yönelik uygulanan vergi teşviklerinin, seçilmiş ülkelerde uygulanan Ar-Ge vergi teşviklerine göre daha az çeşitlilikte ve daha düşük oranda uygulandığı sonucuna varılmıştır.
\end{abstract}

Anahtar Kelimeler: Ar-Ge, Vergi Teşvikleri, Türkiye, Seçilmiş Ülkeler

JEL Sinıflandirmasi: O32, H24, 057

\section{Comparison of Tax Incentives Implemented for R\&D Activities in Turkey and Selected Countries}

\section{ABSTRACT}

Firms are abstaining for $R \& D$ investments, which are more prevalent than the social outcome special effect. In order to prevent companies from acting hesitantly, countries resort to various incentives. As $R \& D$ investments require large capital and a long process, it is not desired to invest in this field by many companies and the prominence of $R \& D$ incentives is put into action here. In this study, it is aimed to compare in terms of diversity, scope and proportion the tax incentive provided for $R \& D$ activities in Turkey and selected countries. According to the $R \& D$ tax incentives applied in selected countries, tax incentives for applied $R \& D$ activities in Turkey are applied at lower rates and less diversity.

Key Words: $R \& D$, Tax Incentives, Turkey, Selected Countries

JEL Classification: $O 32, H 24,057$

\section{GÍRIȘ}

Rekabet edebilirliğin, verimliliği artırarak kalkınmanın ve sürdürülebilir ekonomik refahın devamlılığının idame ettirilebilmesi, yenilikçi ve katma değeri yüksek ürünler üretilmesi ve buna bağlı olarak da dışa bağımlılığın azaltılması artık ülkelerin Ar-Ge'ye yaptıkları yatırımlar ile ölçülebilmektedir. Zira Ar-Ge harcamalarının artması ihracatı tetiklemekte, ihracatın artması da dış ticaret açığını

\footnotetext{
${ }^{1}$ Bu çalışma, Ersan ÖZ’ün danışmanlığında PAÜ SBE Maliye Anabilim Dalı‘nda 2017 yılında yapılan “Ar-Ge Faaliyetlerine Yönelik Uygulanan Vergi Teşviklerinin Ekonomik Büyüme Üzerine Etkisi: Türkiye ve Seçilmiş Ülkelerde Ekonometrik Bir Analiz” adlı Doktora tezinden gözden geçirilerek hazırlanmıştır.

*Arş. Gör. Dr., Adnan Menderes Üniversitesi, Aydın İktisat Fakültesi, Ekonomi ve Finans Bölümü/Aydın, huseyin.kutbay@adu.edu.tr

**Prof. Dr., Pamukkale Üniversitesi, İIBF, Maliye Bölümü/Denizli, ersanoz@ pau.edu.tr
} 
azaltmakta ve ekonominin büyümesine katkı sağlamaktadır. Yine bilgi ve iletişim teknolojilerine yapılan yatırımlar da ülkelerin ekonomisine pozitif katkı sağlayarak dış ticaret açığının kapatılmasında önemli bir rol oynamaktadır. Çünkü Ar-Ge faaliyetlerine ve bilgi ve iletişim teknolojilerine yapılan yatırımlar sonucunda gerçekleştirilen yeni ürünler, süreçler ve üretim teknikleri ya da mevcut durumdaki ürün, süreç ve tekniklerin yenilikçiliğe ayak uyduracak şekilde güncelleştirilmesi neticesinde ülkeler küresel rekabet piyasasında oluşan pastadan önemli bir pay elde etmektedirler ki buda Dünya ülkelerinde yeni bir teknolojiye, ürüne veya sürece sahip olma eğilimini artmıştır. Bu eğilim ise ülkelerin rekabet güçlerinin ve küresel pazar içerisindeki paylarının artmasında önemli bir rol oynayarak ekonomik büyümelerine katkı sağlamıştır. Çünkü Ar-Ge faaliyetlerine yapılan harcamalar ile mevcut olmayan yeni ürün ve araç-gereç üretimi veya yeni yöntem ve süreçlerin gelişimi hız kazanmakta olduğundan ilgili ülkeler için küresel bir ortamda var olan rekabet sürecinde sosyal ve ekonomik refahın ve sürdürülebilir kalkınmanın gelişmesini de beraberinde getirmiştir. Yapılmış olan birçok ampirik analizde firmaların ve endüstrilerin gerçekleştirmiş oldukları Ar-Ge harcamalarının dönüş düzeyleri tahmin edilmeye çalışılmış olup genel olarak Ar-Ge harcamalarının dönüş düzeylerinin yüksek olduğu ancak sosyal getiri oranlarının özel getiri oranlarının çok üzerinde olduğu ortaya koyulmuştur. Bu getiri oranları, Ar-Ge faaliyetlerinin büyüme için ne kadar önemli olduğunu ortaya koymakta ve devlet tarafindan Ar-Ge'ye yapılan sübvansiyonların ve teşviklerin temel gerekçelerinden birini oluşturmaktadır.

\section{TÜRKIYY'DE AR-GE FAALIYETLERINE YÖNELİK UYGULANAN VERGİ TEŞVIKLERİ}

Türkiye'de de Ar-Ge faaliyetleri farklı yıllarda farklı teşvik araçlanı ile veya mevcut teşvik araçlarının oranının ya da kapsamının genişletilmesiyle teşvik edilmiştir. Nitekim 01.01.1986 tarihinden itibaren geçerli olmak üzere Ar-Ge harcamalarına yönelik bir vergi ertelemesi uygulaması getirilmiş olup 3239 say1lı Kanun ile vergi ertelemesi teşviki; mükelleflerin yıl içinde yaptıkları kendi Ar-Ge harcamaları tutarını geçmemek üzere ilgili dönemde ödemeleri gereken yıllık kurumlar vergisinin \%20'sinin kanuni süresinde tahsilinden vazgeçilerek bu orana isabet eden verginin üç y1l süre ile faizsiz olarak ertelenmesi şeklinde başlamıştır. Bu imkân başlangıçta sadece kurumlar vergisi mükelleflerine tanınmışken 4369 sayılı GVK'nın 89. maddesinde düzenleme yapılmak suretiyle gelir vergisi mükelleflerine de yaygınlaştırılmıştır (Yavuz, 2010: 31-32). Bu uygulamada firmaları Ar-Ge faaliyetlerine teşvik eden husus, ödenmesi gereken kurumlar vergisi miktarına (yani kurumlar vergisi oranına) endekslidir (Evci, 2004: 144). Çünkü ilgili yılda dönem bilançosunun zararla sonuçlanması veya istisna uygulamaları nedeniyle kurumlar vergisi matrahının olmaması veya hesaplanan kurumlar vergisinden çeşitli nedenlerle daha önce ödenen vergilerin mahsup edilmesi suretiyle ödenecek kurumlar vergisinin söz konusu olmadığı yıllarda, kanuni süresi içinde ertelenecek vergide bulunmadığından bu uygulamanın firmalar açısından teşvik edici bir yanı olmayacaktır (Çürük ve Türk, 2004: 69). 
2001 y1lında ise Teknoloji Geliştirme Bölgeleri Kanunu kapsamında değişik teşvikler sunulmuştur. Nitekim Türkiye'de 2001 yllında sadece 2 tane teknoloji geliştirme bölgesi bulunuyorken 16 yılda hızlı bir geliştirme göstererek 2017 yılında bu sayı 66'ya yükselmiştir (Bilim ve Teknoloji Genel Müdürlüğü, 2017). Teknoloji geliştirme bölgelerinin yıldan yıla artmasında; bu bölgelerde kurulan şirketlerin münhasıran Ar-Ge ve yazılım faaliyetlerinden elde ettikleri kazançların ve bu şirketlerde çalışan Ar-Ge personelinin ücretlerinin gelir ve kurumlar vergisinden müstesna tutulması ayrıca bu bölgelerde yapılan Ar-Ge faaliyetlerinde çalışan ve ücreti gelir vergisinden istisna olan personelin bu çalışmaları karşılığında elde ettikleri ücretleri üzerinden hesaplanan sigorta primi işveren hissesinin belirli bir kısmının her bir çalışan için beş yıl süreyle Maliye Bakanlığ bütçesine konulacak ödenekten karşılanacak olması etkili olmuştur. 31.07.2004 tarihli Resmi Gazete'de yayımlanan 5228 sayılı Kanun ile uygulanmaya başlanan araştırma ve geliştirme faaliyetlerine yönelik diğer teşvik türü ise Ar-Ge indirimi olup bu teşvik ile gelir ve kurumlar vergisi mükellefleri işletmeleri bünyesinde gerçekleştirdikleri münhasıran yeni teknoloji ve bilgi arayışına yönelik araştırma ve geliştirme harcamaları tutarının \%40'1 oranında hesaplanacak Ar-Ge indiriminden yararlanabilecektir (Can, 2007: 119).

1 Nisan 2008 tarihinde yürürlüğe giren 5746 sayılı Araştırma ve Geliştirme Faaliyetlerinin Desteklenmesi Hakkında Kanun ile ticari kazanç elde eden bütün gelir vergisi mükelleflerinin ve bütün kurumların; faaliyet alanına, büyüklüğüne ve tam veya dar mükellef olup olmadığına bakılmaksızın faydalanacakları Ar-Ge indirimi \% 40 'tan \%100'e çıkarılmış ayrıca 500 ve üzerinde tam zaman eşdeğer Ar-Ge personeli istihdam eden Ar-Ge merkezlerinde o yıl yapılan Ar-Ge ve yenilik harcamasının bir önceki yıla göre artışının da yarısının aynıca indirim konusu yapılmasına izin verilmiştir (Vural, 2009: 501). Bu kanunla gelir vergisi stopaj1 teşviki de getirilmiş olup Ar-Ge ve destek personelinin çalışmaları karşıllğında elde ettikleri ücretlerinin doktoralı olanlar için \%90'1, diğerleri için \%80'i gelir vergisinden müstesna edilmiştir (26814 Sayılı Resmi Gazete, 2008). Bu teşvik başlangıçta çalışanlara yönelik bir uygulama olarak başlatılmasına rağmen 28.02.2009 tarih ve 5838 sayılı Kanun ile yapılan düzenlemeler kapsamında işverenlerin 31.12.2013 tarihine kadar yararlanabileceği bir teşvike dönüştürülmüş olup bu süre 11.06.2013 tarih ve 6487 sayıl1 Kanun ile 31.12.2023 yilına kadar uzatılmıştır (Demirli, 2015: 154). Ayrıca her türlü Ar-Ge ve yenilik faaliyetleri ile ilgili olarak düzenlenen kâğıtlar damga vergisinden müstesnadır hükmüne istinaden, 5746 sayılı Kanun ve yönetmelik kapsamındaki Ar-Ge ve yenilik faaliyetlerinde istihdam edilen personele görevleri ile ilgili olarak yapılan ücret ödemeleri nedeniyle düzenlenen kâğıtlardan da damga vergisi alınmamaktadır (Baştürk, 2012: 99).

5746 sayıl1 kanun kapsamında sunulan bir diğer teşvik ise Ar-Ge ve destek personelinin ücretleri üzerinden hesaplanan sigorta primi işveren hissesi desteğinin yarısının Maliye Bakanlığı bütçesinden karşılanmasıdır. Ancak 11 Eylül 2014 tarihli Resmi Gazete'de yayımlanan 6552 sayılı Torba Kanunu'nun 144 üncü maddesi ile 5746 sayılı Kanun'un 3. maddesinin üçüncü fikrasında yer alan her bir çalışan için beş yıl süreyle ibaresi 12 Eylül 2014 tarihinden itibaren geçerli olmak üzere yürürlükten kaldırılmış olup bu düzenleme uyarınca, 11 Eylül 2014 
tarihinden itibaren, 5746 sayılı Kanun'un geçerlilik tarihi olan 31/12/2023 tarihine kadar, her bir çalışan bazında herhangi bir süre sınırlaması olmaksızın, Ar-Ge ve destek personelinin ücretleri üzerinden hesaplanan sigorta primi işveren hissesi desteğinden yararlanılabilecektir. Bu kanun kapsamında sağlanan bir diğer teşvik ise; örgün öğrenim veren üniversitelerin herhangi bir lisans programından bir y1l içinde mezun olabilecek durumdaki öğrenci, yüksek lisans veya doktora öğrencisi ya da lisans, yüksek lisans veya doktora derecelerinden birini ön başvuru tarihinden en çok beş yıl önce almış kişilerin teknoloji ve yenilik odaklı iş fikirlerini, desteği veren merkezi yönetim kapsamındaki kamu idareleri tarafından desteklenmesi uygun bulunan bir iş planı çerçevesinde, katma değer ve nitelikli istihdam yaratma potansiyeli yüksek teşebbüslere dönüştürebilmelerini teşvik etmek için (Bezirci, 2012: 35) merkezî yönetim kapsamındaki kamu idarelerince bir defaya mahsus olmak üzere, teminat alınmaksızın ve hibe olarak 100.000 TL'ye kadar yapılan teknogirişim sermaye desteğidir (26953 Sayılı Araştırma ve Geliştirme Faaliyetlerinin Desteklenmesine İlişkin Uygulama ve Denetleme Yönetmeliği).

1 Mart 2016 tarihinden itibaren geçerlilik kazanan 6676 Sayılı Araştırma ve Geliştirme Faaliyetlerinin Desteklenmesi Hakkında Kanun ile Bazı Kanun ve Kanun Hükmünde Kararnamelerde Değişiklik Yapılmasına Dair Kanun ile Ar-Ge faaliyetlerine tasarım faaliyetleri de eklenmiş ve gelir vergisi stopaj oranları da (doktoralı personeller ile yükseköğretim kurumlarının temel bilim alanlarından yüksek lisans mezunu olanlar için \%95, yüksek lisans eğitimine devam edenler ile yükseköğretim kurumlarının temel bilimler lisans programlarından lisans mezunu olanlar için \%90, lisans öğrencisi ve altında eğitim derecelerine sahip diğer personeller için \%80 verilecek muhtasar beyanname üzerinden tahakkuk eden vergiden indirilmek üzere terkin edilecektir) artırılmıştır (6676 Sayılı Kanun Mad.1, 2016). Ayrica Ar-Ge veya tasarım merkezi kurabilecek potansiyeli olmayan işletmelere sağlanan teşvik yanında Ar-Ge merkezinin kurulabilmesi için de teşvik sağlanmış olup 6676 sayılı Kanun'un 29 uncu maddesi ile 5746 sayılı Kanun'un 4 üncü maddesine eklenen altıncı fikrayla Bakanlar Kuruluna, Ar-Ge merkezi kurmak için gerekli en az Ar-Ge personeli sayısını sektörler itibarıyla farklılaştırmaya ve 30 olarak belirlenmiş olan (tasarım merkezi kurabilmek için de 10 tam zaman eşdeğer tasarım personeli istihdam edilmesi gerekmektedir) personel sayısını 15'e düşürmeye (tasarım merkezleri için ise yarısına düşürmeye) yetki verilmiştir. 14 Şubat 2017 tarihinde ise bazı giderler (kargo, kurye, vb.) Ar-Ge harcamasına dâhil edilmişken, dişarıdan sağlanan fayda ve hizmetlere de bilimsel danışmanlık hizmetleri dâhil edilmiştir. Böylece hem teşvik alanı genişletilmiş hem de Ar-Ge harcamalarının kapsamı genişletilmiştir (Mazars, 2016: 4-6).

Son olarak Türkiye'nin 2023 hedeflerine ulaşabilmesi, yatırım ortamının iyileştirilmesi, teşvik ve desteklerin kritik, yenilikçi ve katma değeri yüksek teknolojilere yoğunlaştırılması, üretici üzerindeki mali yüklerin daha da azaltılması amacıyla Ar-Ge ve yenilik faaliyetlerine yönelik "7033 sayılı Sanayinin Geliştirilmesi ve Üretimin Desteklenmesi Amacıyla Bazı Kanun ve Kanun Hükmünde Kararnamelerde Değişiklik Yapılmasına Dair Kanun” 1 Temmuz 2017 
tarihli Resmi Gazete'de yayınlanarak yürürlüğe girmiştir. Bu kanun ile Teknoloji Geliştirme Bölgeleri Kanunu nezdinde değişiklikler gerçekleştirilmiş, öğrencilerin teknopark ve Ar-Ge merkezlerinde staj yapmasina yönelik uygulamalarla Yükseköğrenim Kurulu yetkilendirilmiş ve teknoloji geliştirme bölgeleri nezdinde alan tahsisine yönelik damga vergisi yürürlükten kaldırılmış, teknoloji geliştirme bölgelerinde yer alan binalar emlak vergisinden müstesna tutulmuş, temel bilimler alanlarında en az lisans derecesine sahip Ar-Ge personeli istihdam eden Teknoloji Geliştirme Bölgeleri firmalarının, bu personelin her birine ödedikleri aylık ücretin o yıl için uygulanan asgari ücretin aylık brüt tutarı kadarlık kısmının, iki yıl süreyle Bilim, Sanayi ve Teknoloji Bakanlığı bütçesine konulacak ödenekten karşılanacağ 1 belirtilmiş ve devlet yükseköğretim kurumlarının öğretim üyesi kadrosunda fiilen alt1 y1l çalışan öğretim üyelerine, yurt içinde ve yurt dışında alanıyla ilgili Ar-Ge niteliğinde çalışmak üzere, fakülte yönetim kurulunun görüşü ve hizmetin aksamaması için gerekli tedbirlerin alınmış olması kaydıyla ilgili üniversite yönetim kurulu kararı ile öğretim üyesinin hazırladığ 1 çalışma programı değerlendirilerek bir yıl süreyle ücretli izin verilebileceği kararlaştııılmıştır (30111 sayllı Resmi Gazete, 2017).

\section{SEÇILMISŞ ÜLKELERDE AR-GE FAALIYETLERINE YÖNELIKK UYGULANAN VERGİ TEŞVIKLERİ}

İşletmelere yönelik Ar-Ge vergi teşviki sunan gerek OECD gerekse OECD üyesi olmayan ülkelerin sayısında özellikle son yıllarda önemli bir artış kaydedilmiştir. 1995 y1lında 12 OECD ülkesi Ar-Ge faaliyetleri için vergi teşviki uygularken, 2004 yılında 18 ülke, 2011 yılında 26 ülke, 2015 yılında ise 28 ülke Ar-Ge faaliyetlerini vergi teşviki ile desteklemiş olup bu politika aracı özellikle son yıllarda işletmelerin araştırma ve deneysel gelişimini artırmak için popüler bir politika aracı haline gelmiştir (OECD, 2017).

Firmaların Ar-Ge'ye ayırdığ 1 harcamaların hacmine veya artışına bağlı olarak vergi yükünde bir azalma önermekte olan bu enstrümanın popülerliği, gerek kurumlar vergisi gerekse mevcut sistem yoluyla uygulanmasının oldukça basit olması gerçeğinden ve hem yetkililerin hem de firmaların yanındaki düşük ek idari maliyetleri ifade etmesinden kaynaklanmaktadır. Ayrıca Ar-Ge vergi teşvikleri, desteklenen Ar-Ge faaliyetinin içeriği açısından tarafsızdır ve küçük firmalar ve hizmet firmaları da dâhil olmak üzere her türlü büyüklükteki firmaya sunulmaktadır. Bunlara ek olarak uzun vadeli bir süreç için, şirketlerin finansal planlama ve Ar-Ge kararlarına güvenilir bir temel sağlamaktadır (Köhler vd., 2012: 3). Ülkeler ekonomik, mali ve sosyal yapılarına veya gelişmişlik düzeylerine göre araştırma ve geliştirme faaliyetlerine yönelik birbirinden farklı türde ve oranlarda teşvik araçları uygulamakta olup Ar-Ge faaliyetleri kapsamında ülkelerde uygulanan doğrudan ve dolaylı teşvik araçları Tablo 1'de gösterilmiştir.

Tablo 1'de görüldüğü üzere seçilmiş ülkelerin hepsi araştırma ve geliştirme faaliyetlerinin desteklenmesi için birbirinden farklı teşvik araçlarına başvurmuştur. Bu teşvik araçlarından vergi kredisi Türkiye'de uygulanmamakla birlikte seçilmiş ülkelerin neredeyse tamamı (Çin hariç) tarafından uygulanmıştır. İspanya ve Kanada ülkeleri haricinde seçilmiş ülkelerin Ar-Ge harcamalarının teşviki için 
başvurmuş olduğu bir diğer teşvik aracı ise Ar-Ge indirimidir. Matrahtan indirim şeklinde uygulanan Ar-Ge indirimi Çin, Danimarka, Hollanda, İngiltere ve Rusya'da süper Ar-Ge indirimi (\%100'ün üzerinde) şeklinde uygulanmaktadır. Gelir vergisi stopajı teşviki, Türkiye'de uygulanmakta olup seçilmiş ülkelerden ise sadece Hollanda'da uygulanmaktadır. Vergi tatili uygulaması ise Fransa, Çin ve Rusya'da uygulanmakta olup bu teşvik genellikle $(2+3)$ veya $(5+5)$ şeklinde uygulanmaktadır. Vergi tatilinin ilk dönemleri \%100 oranında, ikinci dönemleri ise $\% 50$ oranında muaf şeklinde uygulanmaktadır. İndirimli kurumlar vergisi oranı ise seçilmiş ülkelerden Fransa, Çin, Hollanda ve Rusya tarafından uygulanmaktadır. $\mathrm{Bu}$ teşvik arac1 ileri/yüksek teknolojik ürün, süreç, sistem ve hizmet üreten firmalara yönelik olarak yasal kurumlar vergisi oranının indirimli şekilde uygulanmasını ifade etmektedir. Seçilmiş ülkelerden Fransa, Hollanda, İngiltere ve İspanya'da uygulanmakta olan patent kutusu teşvikinde ise patent haklarının veya patentlerin satışından veya lisanslanmasından elde edilen kazançlar için indirimli kurumlar vergisi oranı uygulanmaktadır.

Tablo 1: Seçilmiş Ülkelerde Uygulanan Ar-Ge Teşvikleri

\begin{tabular}{|c|c|c|c|c|c|c|c|c|c|c|c|}
\hline $\begin{array}{l}\frac{\vec{v}}{\bar{v}} \\
: \vec{D}\end{array}$ & 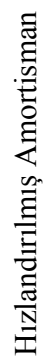 & 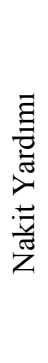 & 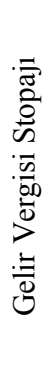 & 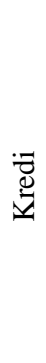 & 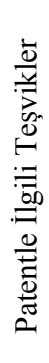 & 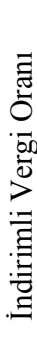 & 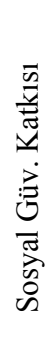 & 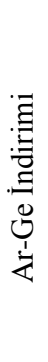 & 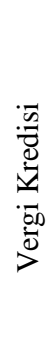 & 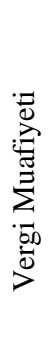 & $\begin{array}{l}\bar{J} \\
\overline{0} \\
\overline{0} \\
\overline{0} \\
\overline{0}\end{array}$ \\
\hline $\mathrm{ABD}$ & $\checkmark$ & & & & & & & $\checkmark$ & $\checkmark$ & & \\
\hline Avusturya & & $\checkmark$ & & $\checkmark$ & & & & $\checkmark$ & $\checkmark$ & & \\
\hline Danimarka & & & & & & & & $\checkmark$ & $\checkmark$ & & \\
\hline Fransa & $\checkmark$ & $\checkmark$ & & $\checkmark$ & $\checkmark$ & $\checkmark$ & $\checkmark$ & $\checkmark$ & $\checkmark$ & & $\checkmark$ \\
\hline Çin & & & & & & $\checkmark$ & & $\checkmark$ & & $\checkmark$ & $\checkmark$ \\
\hline Hollanda & $\checkmark$ & $\checkmark$ & $\checkmark$ & & $\checkmark$ & $\checkmark$ & $\checkmark$ & $\checkmark$ & $\checkmark$ & & \\
\hline İspanya & $\checkmark$ & $\checkmark$ & & & $\checkmark$ & & & & $\checkmark$ & $\checkmark$ & \\
\hline İngiltere & $\checkmark$ & $\checkmark$ & & & $\checkmark$ & & & $\checkmark$ & $\checkmark$ & & \\
\hline Kanada & $\checkmark$ & $\checkmark$ & & & & & & & $\checkmark$ & & \\
\hline Rusya & $\checkmark$ & & & & & $\checkmark$ & $\checkmark$ & $\checkmark$ & $\checkmark$ & $\checkmark$ & $\checkmark$ \\
\hline
\end{tabular}

Kaynak: Worldwide R\&D Incentives Reference Guide, 2015: 2.

\section{TÜRKIYYE VE SEÇİLMIŞ ÜLKELERDE UYGULANAN AR-GE VERGI TEŞVIKLERINIIN KARŞILAŞTIRILMASI}

Ekonomik verimlilik ve büyüme performansının temel faktörleri olarak kabul edilen araştırma-geliştirme ve yenilik faaliyetleri hemen hemen bütün ülkeler kapsamında doğrudan ya da dolaylı olarak desteklenmekte olup Ar-Ge vergi teşvikleri, hükümetlerin bu tür faaliyetleri teşvik etmesinde olası politika 
araçlarından birini oluşturmaktadır. Ülkeler, içerisinde bulundukları ekonomik şartlara veya mevzuat yapılarına göre araştırma ve geliştirme faaliyetlerini farklı teşvik türleri ile cesaretlendirebilmektedirler. Nitekim özel sektör Ar-Ge ve yenilik faaliyetleri bazı ülkelerde vergi teşvikleri (Ar-Ge indirimi, süper Ar-Ge indirimi, indirimli kurumlar vergisi oranı, gelir vergisi stopaj desteği, hızlandırılmış amortisman, vergi kredisi, iade edilebilir yatırım vergi kredisi, vergi ertelemesi, patent kutusu rejimi, mülk ve arazi vergisi teşviki, sosyal güvenlik katkı paylarının indirimli olarak uygulanması vb.) ile bazı ülkelerde doğrudan finansman (hibe, kredi, Ar-Ge hizmeti satın almak vb.) yöntemiyle bazı ülkelerde ise doğrudan ve dolaylı teşvik araçlarının birlikte kullanılması ile desteklenmektedir. Farklı ülkeler tarafindan kullanılan Ar-Ge vergi teşviklerinden çoğu, Ar-Ge masraflarını yüklenen şirketlerin kurumlar vergisi yükümlülügünü azaltmayı amaçlamaktadır.

Ülkelerin Ar-Ge çalışmalarını teşvik etmek için kullandıkları temel kurumlar vergisi teşvikleri, vergiye tabi gelirden Ar-Ge harcamalarının indirilmesi şeklinde sunulmakta olup bu vergi teşviki ile firmalar tarafından gerçekleştirilen Ar-Ge harcamalarının artırılması amaçlanmaktadır. Araştırma ve geliştirme faaliyetleri için sunulan teşviklerin boyutu da bu destek araçlarının çeşitliliği gibi ülkeden ülkeye farkl1lıklar gösterebilmektedir. Nitekim sunulan desteklerin boyutu, faaliyette bulunulan endüstrinin niteliğine, işletmenin faaliyette bulunduğu alanda sahip olduğu teknolojik altyapıya veya karşı karşıya kalınan rekabetin şiddetine bağlı olarak ülkeden ülkeye değişmektedir.

\section{A. Ar-Ge İndirimi Açısından Karşılaştırma}

Ar-Ge faaliyetlerini destekleyen ülkelerin genelinde, Ar-Ge kapsamında gerçekleştirilen harcamalar ya matrahtan indirilmekte ya da amortismana tabi tutularak giderleştirilmekte olup Tablo 2'de ele alınan ülkelerde Ar-Ge faaliyeti kapsamında yapılan giderlerin Ar-Ge indirimine tabi tutulmasıyla firmalara ne kadarlık bir vergisel avantaj sağladığı gösterilmektedir. Bu teşvikin etkinliğini ölçmek için ülkelerde uygulanan Ar-Ge indirim oranları ve kurumlar vergisi oranları dikkate alınmıştır.

Çalışmada ele alınan ülkelerden bazılarında Ar-Ge indirimi uygulanmakta iken bazılarında hızlandırılmış amortisman yöntemi tercih edilmiştir. Sağlanan teşvik miktarının hesaplanmasında Ar-Ge faaliyetinde bulunan herhangi bir firmanın vergi öncesi gelirinin 1 Milyon ve Ar-Ge harcamasının 100.000 olduğu varsayılmıştır.

Tablo 2'de görüldügüü üzere ülkelerde Ar-Ge faaliyeti kapsamında yapılan giderlerin Ar-Ge indirimine tabi tutulmasıyla sağlanan avantaj, Ar-Ge indirim oranına ve uygulanan kurumlar vergisi oranına göre ülkeden ülkeye değişiklik gösterebilmektedir. ABD'de Ar-Ge indirimi uygulanmakla birlikte bu uygulamay1 tercih etmeyen firmalar için 60 aydan az olmamak şartıyla hızlandırılmış amortisman yöntemi de geçerli olup iki uygulamadan birini tercih etme hakk1 mükelleflere bırakılmıştır.

Fransa'da cari araştırma ve geliştirme harcamaları, harcamanın gerçekleştiği yıl içerisinde vergilendirilebilir gelirden $\% 100$ oranında indirilebilmekte iken Ar-Ge sermaye harcamaları ise amortisman uygulamasına 
tabi tutulmaktadır. Ar-Ge faaliyetlerinde kullanılan makine ve ekipman için yapılan Ar-Ge sermaye harcamaları ise genellikle normal amortisman yöntemiyle 5 y1l içinde amorti edilmekte ya da azalan bakiyeler yöntemine göre \%40 oranında amortismana tabi tutularak indirime tabi tutulmaktadır.

İspanya'da şirketler Ar-Ge faaliyetlerinde kullandıkları maddi ve maddi olmayan varlıkların amortismanlarını serbestçe indirebilmektedirler. Ancak binalar için özel bir kural geçerli olup, Ar-Ge faaliyetleri için kullanılan binaların bir kısmı amortismana tabi tutulabilmekte ve bu amortismanın 10 yıl boyunca normal amortisman yöntemi ile ayrılması gerekmektedir.

Danimarka'da vergi mükellefleri genel olarak şirket faaliyetleri ile bağlantılı olarak gerçekleştirilen deneysel ve araştırma harcamalarını giderlerin yapıldığı gelir yılında düşmeyi veya masrafların gerçekleştiği yıl içinde ve takip eden 4 y1l içerisinde eşit tutarda itfa edebilmeyi seçebilmektedirler.

Tablo 2: Türkiye ve Seçilmiş Ülkelerde Ar-Ge İndirimi Teşvik Miktarı (€)

\begin{tabular}{|c|c|c|c|c|c|c|}
\hline Ülkeler & $\begin{array}{c}\text { Vergi } \\
\text { Öncesi } \\
\text { Gelir }\end{array}$ & $\begin{array}{c}\text { Ar-Ge } \\
\text { Harcamas1 }\end{array}$ & $\begin{array}{c}\text { Ar-Ge } \\
\text { İndirim } \\
\text { Oranı }\end{array}$ & $\begin{array}{c}\text { Ar-Ge } \\
\text { Indirim } \\
\text { Tutarı }\end{array}$ & $\begin{array}{l}\text { KV } \\
\text { Oran1 }\end{array}$ & $\begin{array}{c}\text { Sağlanan } \\
\text { Teşvik }\end{array}$ \\
\hline $\mathrm{ABD}$ & 1 Milyon & 100.000 & $\% 100$ & 100.000 & $\% 35$ & $\begin{array}{l}35.000 \\
(0,035)\end{array}$ \\
\hline Avusturya & 1 Milyon & 100.000 & $\begin{array}{c}\% 25 \text { ve } \\
\% 35^{2} \\
\end{array}$ & 27.000 & $\% 25$ & $\begin{array}{c}6.750 \\
(0,00675) \\
\end{array}$ \\
\hline Çin & 1 Milyon & 100.000 & $\% 150$ & 150.000 & $\% 25$ & $\begin{array}{c}37.500 \\
(0,0375)\end{array}$ \\
\hline Danimarka & 1 Milyon & 100.000 & $\% 115$ & 115.000 & $\% 22$ & $\begin{array}{c}25.300 \\
(0,0253)\end{array}$ \\
\hline Fransa & 1 Milyon & 100.000 & $\% 100$ & 100.000 & $\% 33.33$ & $\begin{array}{c}33.330 \\
(0,0333)\end{array}$ \\
\hline Hollanda & 1 Milyon & 100.000 & $\% 160$ & 160.000 & $\% 25$ & $\begin{array}{c}40.000 \\
(0,04)\end{array}$ \\
\hline İngiltere & 1 Milyon & 100.000 & $\begin{array}{l}\% 130^{3} \\
(\% 30)^{4}\end{array}$ & 130.000 & $\% 19$ & $\begin{array}{c}24.700 \\
(0.0247)\end{array}$ \\
\hline İspanya & 1 Milyon & 100.000 & \multicolumn{4}{|c|}{$\begin{array}{l}\text { Hizlandırılmış Amortisman Yöntemi } \\
\text { Uygulanmaktadır. KV Oranı }(\% 25)\end{array}$} \\
\hline Kanada & 1 Milyon & 100.000 & \multicolumn{4}{|c|}{$\begin{array}{l}\text { Hizlandırılmış Amortisman Yöntemi } \\
\text { Uygulanmaktadır. KV Oranı }(\% 15)\end{array}$} \\
\hline Rusya & 1 Milyon & 100.000 & $\% 150$ & 150.000 & $\% 20$ & $\begin{array}{l}30.000 \\
(0,03)\end{array}$ \\
\hline Türkiye $^{5}$ & 1 Milyon & 100.000 & $\% 100$ & 110.000 & $\% 20$ & $\begin{array}{l}22.000 \\
(0,022)\end{array}$ \\
\hline
\end{tabular}

Kaynak: Yazarlar tarafından oluşturulmuştur.

\footnotetext{
${ }^{2}$ Geçmiş 3 yılın Ar-Ge harcaması ortalaması için \%25 oranı uygulanmak ta olup Ar-Ge harcaması ortalaması 80.000 olarak alınmıştır. 20.000 için ise $\% 35$ oranı uygulanmıştır.

${ }^{3}$ KOBI'ler için Ar-Ge indirim oranı \%130'dur.

${ }^{4} 31$ Mart 2016'dan itibaren, büyük işletmeler için \%30 indirim yapılmayacak olup bu tarihten itibaren harcamaya dayalı nakit krediye başvurabilmekledirler.

${ }^{5} 500$ ve üzerinde tam zaman eşdeğer Ar-Ge personeli istihdam eden Ar-Ge merkezleri için bir önceki yıl Ar-Ge harcaması 80.000 olarak dikkate alınmıştır.
} 
Ar-Ge indirim teşvikinden hangi ülkenin daha fazla yararlandığının belirlenmesinde, Ar-Ge indirim oranı ve kurumlar vergisi oranı önemli bir öneme sahiptir. Çünkü Ar-Ge indirim oranı ne kadarlık Ar-Ge harcamasının vergi matrahına dâhil edilmeyeceğini gösterirken, kurumlar vergisi oranı ise Ar-Ge indirim oranıyla hesaplanan Ar-Ge harcaması neticesinde ne kadarlık vergiden vazgeçildiğini göstermektedir. Yüksek Ar-Ge indirim oranına ve kurumlar vergisi oranına sahip olan ülkelerde vazgeçilen vergi miktarı da dolayısıyla sağlanan teşvik miktarı da yüksek olmaktadır. İspanya ve Kanada'da Ar-Ge indirimi teşviki uygulanmaz iken diğer ülkelerde farklı oranlarda bu teşvik uygulanmaktadır. Avusturya'da ve Türkiye'de ise Ar-Ge indirimi diğer ülkelere göre daha farklı bir şekilde hesaplanmaktadır. Avusturya'da iki farklı Ar-Ge indirim oranı (\%25/\%35) mevcut olup bunlardan birincisi geçmiş 3 yılın Ar-Ge harcamalarının ortalaması için geçerli iken diğeri ise cari dönem harcamalarının geçmiş 3 yılın $\mathrm{Ar}-\mathrm{Ge}$ harcamalarının ortalamasını aşan kısmı için geçerli olmaktadır. Türkiye'de cari dönemde gerçekleştirilen Ar-Ge harcamalarının tamamına \%100 Ar-Ge indirimi uygulanırken, geçmiş yıl Ar-Ge harcamasını aşan kısmın yarısı da Ar-Ge indirimi olarak dikkate alınmaktadır. İngiltere'de Ar-Ge indirim oranı diğer ülkelerden farklı olarak tek bir firma bazında olmayıp KOBİ (\%130) ve büyük şirket (\%30) kapsamında ayrı ayrı olarak uygulanmaktadır.

Diğer ülkelerde ise geçmiş yıllardaki Ar-Ge harcamaları Ar-Ge indirim teşvikinin hesaplanmasında dikkate alınmamaktadır. Tablo 2' deki ülkelerde Ar-Ge faaliyetinde bulunan herhangi bir firmanın vergi öncesi gelirinin 1 milyon $€$ ve ArGe harcamasının $100.000 €$ olduğu durumda ne kadarlık bir vergi teşviki sağladığ hesaplanmıştır. İncelen ülkelerde faaliyet gösteren firmalardan en fazla faydayı (40.000€) Hollanda'da Ar-Ge faaliyeti gerçekleştiren firma sağlamışken en az faydayı (6.750€) ise Avusturya'da Ar-Ge faaliyeti gerçekleştiren firma elde etmiştir. Diğer ülkelerdeki firmaların elde etmiş olduğu teşvik miktarı ise sırasıyla Çin (37.500€), ABD (35.000 €), Fransa (33.330€), Rusya (30.000€), Danimarka (25.300€), İngiltere $(24.700 €)$ ve Türkiye (22.000€) olarak belirlenmiştir. Türkiye Ar-Ge indirimi uygulayan ülkeler arasında Avusturya'dan sonra sondan ikinci sırada yer almaktadır. Ar-Ge indirim teşviki sıralamasında ele alınan ülkelerde son sırada yer alan Avusturya'da Ar-Ge indirim teşviki çok cazip olmaması nedeniyle 31 Aralık 2010 tarihinde yürürlükten kaldırılmıştır.

\section{B. Vergi Kredisi Açısından Karșılaştırma}

Yenilikçiliğin meydan okuması, modern bilgi temelli bir ekonominin büyümesinde önemli bir rol oynamaktadır. İster yeni ürünler icat etmek, ister çığır açan araştırmalar yapmak, ister endüstriyel süreçleri geliştirmek ve genişletmek olsun, bir işletmenin geleceği büyük ölçüde yenilik yatırımlarının kalitesine ve sürdürülebilirliğine bağlı olmaktadır. Nitekim bunun farkında olan birçok ülkede yenilikle sonuçlanan Ar-Ge faaliyetlerine yönelik teşvikler sunulmakta olup bu teşviklerin amacı şirketlerin mevcut rekabet araçlarından yararlanarak küresel rekabetçi bir pazarda öne çıkma yeteneklerini arttırmalarına yardımcı olmaktır. Dünya üzerindeki hükümetler, firmalardaki Ar-Ge'yi desteklemek, yenilikçilik ve ekonomik büyümeyi teşvik etmek için doğrudan destek önlemlerine ek olarak 
giderek artan şekilde vergi teşviklerinden de yararlanmaktadırlar. Zamanla, Ar-Ge harcamaları için sunulan teşviklerden olan vergi kredileri, vergi ödeneklerinden (Ar-Ge indiriminden) daha popüler hale gelmiştir. Zira Avusturya'da nitelikli ArGe harcamaları için uygulanan Ar-Ge indirimi, firmaların Ar-Ge harcamaları üzerinde büyük bir etki oluşturmadığı için 31 Aralık 2010 tarihinden itibaren yürüklükten kaldırılmış olup bunun yerine 2011 yılından itibaren \%8 olan Ar-Ge prim oranı \%10'a ve 2016 yılından itibaren de \%12'ye yükseltilmiştir. Hollanda' da ise 1 Ocak 2016 tarihinden itibaren Ar-Ge indirimi, ücret vergi kredisi ile birleştirilmiştir. Ar-Ge indirimi ve vergi kredisi teşvikinin her ikisi de işletmelerin Ar-Ge maliyetlerini azaltmaktadır. Vergi ödenekleri, Ar-Ge'ye yatırım yapan firmaların gerçek Ar-Ge harcamalarından daha fazlasını vergilendirilebilir gelirden düşmesine izin verirken, vergi kredileri ise ödenecek kurumlar vergisine karş1 uygulanan Ar-Ge harcamalarının belirli bir yüzdesini ifade etmektedir. Buna göre, Ar-Ge faaliyetleri için verilen ödenek, vergiye tabi gelirden bir kesinti iken vergi kredisi ise nihai vergi yükümlülüğüne karşı uygulanan bir kesintidir.

Tablo 3'de seçilmiş ülkelerde vergi kredisi uygulamasının karşılaştırılması bir örnek üzerinden yapılmış olup bütün ülkelerde Ar-Ge faaliyetinde bulunan firmaların vergi öncesi geliri ve Ar-Ge harcamaları aynı kabul edilmiştir. Ülkelerin birbirinden fark1 oranlarda ve miktarda vergi kredisi sunduğu Tablo 3'de görülmekte olup Türkiye ve Çin'de Ar-Ge faaliyetlerine yönelik vergi kredisi teşviki uygulanmadığından bu ülkelere yer verilmemiştir. Ar-Ge faaliyetleri için ülkelerin sunmuş oldukları vergi kredisi hacim bazlı, artırımlı ya da azaltılmış şekilde sağlanmıştır. Ele alınan ülkelerden İspanya' da hem hacim bazlı hem de artırımlı olmak üzere karma bir vergi kredisi teşviki uygulanmaktadır. Cari dönem Ar-Ge harcamaları için hacim bazlı \%35 vergi kredisi oranı uygulanırken ayrıca geçmiş 2 yılın Ar-Ge harcamaları ortalamasını aşan kısma artırımlı olarak \%42 oranında da vergi kredisi uygulanmaktadır. Hollanda'da ise azaltılmış vergi kredisi oranı uygulanmakta olup cari dönemde gerçekleştirilen ilk 350.000€ için \%32, aşan kısım için ise \%16 oranında vergi kredisi uygulanmaktadır. Vergi kredisinin hesaplama yöntemleri de vergi kredisi oranları gibi ülkeden ülkeye değişiklikler gösterebilmektedir. Zira İngiltere'de yararlanılacak vergi kredisi doğrudan yapılan Ar-Ge harcama miktarından hesaplanıp çıkan miktar kurumlar vergisinden düşülmemekte olup hesaplanan vergi kredisi matraha eklenmekte ve bunun üzerinden kurumlar vergisi hesaplanmakta daha sonra kurumlar vergisinden hesaplanan vergi kredisi düşülmektedir (Kurumlar vergisi matrahı; 4.000.000 + $220.000=4.220 .000 €$ olacaktır). Rusya'da vergi kredisi, Ar-Ge harcamaları üzerinden değil ödenecek kurumlar vergisi üzerinden hesaplanmaktadır.

Danimarka'da vergi kredisi negatif vergi şeklinde uygulanmakta olup ArGe harcaması nedeniyle bütçesi zararla sonuçlanmışsa firmaya vergi kredisi verilmektedir. Genellikle likidite kısıtlı firmaları (genç ve küçük ölçekli şirketler) hedef almakta olan Danimarka vergi kredisinin finansman elde etmek için daha büyük engellerle karşı karşıya kalan genç firmalara ek destek sağlanması yönünden en iyi uygulama olduğu kabul edilmektedir. Çünkü negatif vergi, Ar-Ge faaliyetleri 
henüz gelir getirmediğinde, bu küçük firmaların başlangıç aşamasındaki likiditesini güçlendirmektedir. ABD'de ise araştırma ve deneme vergi kredisi, alternatif artan mekanizmalı kredi, alternatif basitleştirilmiş kredi, temel araştırma kredisi ve klinik

Tablo 3: Seçilmiş Ülkelerde Vergi Kredisi Uygulamasının Karşılaş̧ırılması

\begin{tabular}{|c|c|c|c|c|c|c|c|c|c|c|}
\hline Ülkeler & $\begin{array}{c}\text { Vergi } \\
\text { Öncesi } \\
\text { Gelir } \\
\text { (A) }\end{array}$ & $\begin{array}{c}\text { Ar-Ge } \\
\text { Harca } \\
\text { mas1 } \\
\text { (B) }\end{array}$ & $\begin{array}{c}\text { Kurum } \\
\text { lar } \\
\text { Vergis } \\
\text { i } \\
\text { Matrah } \\
1(\mathrm{C})= \\
\text { (A-B) }\end{array}$ & $\begin{array}{l}\text { Kurum } \\
\text { lar } \\
\text { Vergis } \\
\text { i Oranı } \\
\text { (D) }\end{array}$ & $\begin{array}{c}\text { Ödene } \\
\text { cek } \\
\text { Kurum } \\
\text { lar } \\
\text { Vergis } \\
\text { i } \\
(\mathrm{E})= \\
\left(\mathrm{C}^{*} \mathrm{D}\right)\end{array}$ & $\begin{array}{c}\text { Vergi } \\
\text { Kredi } \\
\text { Oran1 } \\
\text { (F) }\end{array}$ & $\begin{array}{c}\text { Kredi } \\
\text { Mikt } \\
\text { ar1 } \\
(\mathrm{G})= \\
\left(\mathrm{B}^{*} \mathrm{~F}\right. \\
)\end{array}$ & $\begin{array}{l}\text { Ödene } \\
\text { n KV } \\
(\mathrm{H})= \\
(\mathrm{E}-\mathrm{G})\end{array}$ & $\begin{array}{c}\text { Kred } \\
\text { i } \\
\text { Sonr } \\
\text { as1 } \\
\text { KV } \\
\text { Oran } \\
1(\mathrm{I}) \\
= \\
(\mathrm{H} / \mathrm{C} \\
)\end{array}$ & $\begin{array}{c}\text { Kred } \\
\text { i } \\
\text { Sonr } \\
\text { as1 } \\
\text { KV } \\
\text { Fark1 } \\
\text { (i) }= \\
\text { (D-I) }\end{array}$ \\
\hline $\begin{array}{c}\text { Avustur } \\
\text { ya }\end{array}$ & $\begin{array}{c}6.000 . \\
000\end{array}$ & $\begin{array}{c}2.000 .0 \\
00\end{array}$ & 000 & $\% 25$ & 000 & $\% 12$ & $00 €$ & $0 €$ & 0,19 & 0,06 \\
\hline Fransa & $\begin{array}{c}6.000 . \\
000\end{array}$ & $\begin{array}{c}2.000 .0 \\
00\end{array}$ & $\begin{array}{c}4.000 . \\
000\end{array}$ & $\begin{array}{c}\% 33,3 \\
3 \\
\end{array}$ & $\begin{array}{c}1.333 \\
200\end{array}$ & $\% 30^{6}$ & $\begin{array}{c}600.0 \\
00 €\end{array}$ & $\begin{array}{c}733.20 \\
0 € \\
\end{array}$ & $\begin{array}{c}0,18 \\
33\end{array}$ & 0,15 \\
\hline $\begin{array}{c}\text { Holland } \\
\mathrm{a}^{7}\end{array}$ & $\begin{array}{c}6.000 . \\
000\end{array}$ & $\begin{array}{c}2.000 .0 \\
00 \\
\end{array}$ & $\begin{array}{c}4.000 . \\
000\end{array}$ & $\% 25$ & $\begin{array}{c}1.000 . \\
000\end{array}$ & $\%$ & $\begin{array}{c}376.0 \\
00 €\end{array}$ & $\begin{array}{c}624.00 \\
0 €\end{array}$ & $\begin{array}{c}0,15 \\
6 \\
\end{array}$ & $\begin{array}{c}0,09 \\
4 \\
\end{array}$ \\
\hline İspanya & $\begin{array}{c}6.000 . \\
000\end{array}$ & $\begin{array}{c}2.000 .0 \\
00\end{array}$ & $\begin{array}{c}4.000 . \\
000\end{array}$ & $\%$ & $\begin{array}{c}1.000 . \\
000\end{array}$ & $\begin{array}{l}\% 35 / \\
\% 42\end{array}$ & $\begin{array}{c}952.0 \\
00 €\end{array}$ & $\begin{array}{c}48.000 \\
€\end{array}$ & $\begin{array}{c}0,01 \\
2\end{array}$ & $\begin{array}{c}0,23 \\
8\end{array}$ \\
\hline $\begin{array}{c}\text { İngilter } \\
\mathrm{e}\end{array}$ & $\begin{array}{c}6.000 . \\
000\end{array}$ & $\begin{array}{c}2.000 .0 \\
00\end{array}$ & $\begin{array}{c}4.220 . \\
000\end{array}$ & $\% 19$ & $\begin{array}{c}801.80 \\
0\end{array}$ & $\% 11$ & $\begin{array}{c}220.0 \\
00 €\end{array}$ & $\begin{array}{c}581.80 \\
0 €\end{array}$ & $\begin{array}{c}0,13 \\
79 \\
\end{array}$ & $\begin{array}{c}0,05 \\
21 \\
\end{array}$ \\
\hline Rusya & $\begin{array}{c}6.000 . \\
000\end{array}$ & $\begin{array}{c}2.000 .0 \\
00\end{array}$ & $\begin{array}{c}4.000 . \\
000\end{array}$ & $\% 20$ & $\begin{array}{c}800.00 \\
0\end{array}$ & $\% 50$ & $\begin{array}{c}400.0 \\
00 €\end{array}$ & $\begin{array}{c}400.00 \\
0 €\end{array}$ & 0,10 & 0,10 \\
\hline $\begin{array}{c}\text { Danima } \\
\text { rka }\end{array}$ & $\begin{array}{c}6.000 . \\
000\end{array}$ & $\begin{array}{c}2.000 .0 \\
00\end{array}$ & $\begin{array}{c}4.000 . \\
000\end{array}$ & 2 & -- & $22^{9}$ & $\begin{array}{c}440.0 \\
00 €\end{array}$ & --- & 0,00 & 0,22 \\
\hline Kanada & $\begin{array}{c}6.000 . \\
000\end{array}$ & $\begin{array}{c}2.000 .0 \\
00\end{array}$ & $\begin{array}{c}4.000 . \\
000\end{array}$ & $\% 15$ & $\begin{array}{c}600.00 \\
0 €\end{array}$ & $\% 15$ & $\begin{array}{c}300.0 \\
00 €\end{array}$ & $\begin{array}{c}300.00 \\
0 €\end{array}$ & $\begin{array}{c}0,07 \\
5\end{array}$ & $\begin{array}{c}0,07 \\
5\end{array}$ \\
\hline $\mathrm{ABD}^{10}$ & $\begin{array}{c}6.000 . \\
000\end{array}$ & $\begin{array}{c}2.000 .0 \\
00 \\
\end{array}$ & $\begin{array}{c}4.000 . \\
000\end{array}$ & $\% 35$ & $\begin{array}{c}1.400 . \\
000\end{array}$ & $\% 20$ & $\begin{array}{c}400.0 \\
00 €\end{array}$ & $\begin{array}{c}1.000 . \\
000\end{array}$ & 0,25 & 0,10 \\
\hline
\end{tabular}

araştırmalar ve ilaç testlerine yönelik vergi kredisi olmak üzere birden çok vergi kredisi uygulaması mevcut olup Tablo 3'deki hesaplamada araştırma ve deneme vergi kredisi dikkate alınmıştır.

Tablo 3'deki vergi kredisi sonrası ödenecek vergilerin kurumlar vergisi matrahına oranı dikkate alındığında, vergi kredisi en fazla İspanya'da $(0,238)$ en az ise İngiltere'de $(0,0521)$ etkili olmuştur. Diğer ülkelerdeki sıralama ise büyükten küçüğe doğru Danimarka, Fransa, Rusya ve ABD (iki ülkede aynı şekilde etki olmuştur), Hollanda, Kanada ve Avusturya şeklinde gerçekleşmiştir. Vergi

\footnotetext{
${ }^{6} 1$ Ocak 2015 tarihinden itibaren ülkenin Avrupa yakası dışında kalan bölgelerinde Ar-Ge faaliyetinde bulunan şirketler için vergi kredisi oranı 100 milyon avroya kadar \%50, bu tutarı aşan kısım için ayrıca \%5 olarak uygulanmıştır. Normal şartlarda kredi oranı 100 milyon avroya kadar \%30, aşan kısım için ise $\% 5$ tir.

${ }^{7}$ Hollanda'da ilk $350.000 €$ için $\% 32$, aşan kısım için ise \%16 vergi kredisi uygulanmaktadır.

${ }^{8}$ İspanya'da hacim bazlı ve artırımlı olmak üzere karma bir vergi kredisi teşviki uygulanmaktadır. Cari dönem ArGe harcamaları için \%35 olan vergi kredisi oranı ayrıca geçmiş 2 yılın Ar-Ge harcamaları ortalamasını aşan kısma $\% 42$ olarak uygulanmaktadır. Geçmiş iki yılın Ar-Ge harcamasının $(1.200 .000+1.600 .000)$ ortalaması 1.400.000 olarak kabul edilmiştir. Buna göre ortalamayı aşan kısım $600.000 €$ 'dur.

${ }^{9}$ Danimarka'da Ar-Ge harcaması zarar tutarı olarak değerlendirilmiş̧tir.

${ }^{10} \mathrm{Ar}-\mathrm{Ge}$ harcaması $(2.000 .000 €)$ cari yıl Ar-Ge harcamasından taban miktar çıkarıldıktan sonra kalan kısmı teşkil edecek şekilde ele alınmıştır.
} 
kredisinin ülkelerde daha fazla etkili olmasında; Ar-Ge faaliyetleri için verilen vergi kredisinin oran1, kurumlar vergisinin oran1 ve vergi kredisinin hacim bazl1, artırımlı ve azaltılmış şekilde uygulanması önemli bir rol oynamaktadır. Çünkü vergi kredisinin etkinliği kurumlar vergisinin oranına bağlı olmaktadır. Zira kurumlar vergi oranının düşük, vergi kredisi oranının yüksek olduğu bir ülkede ArGe faaliyeti gerçekleştiren bir firmanın hiç vergi vermemesi mümkündür. Hatta kredilerin iade edilmesi durumunda firmanın gideri yerine geliri olmaktadır.

\section{Karşılaştırma}

\section{Gelir Vergisi Stopajı ve Sosyal Güvenlik Katkı Payı Açısından}

Gelir vergisi stopaj teşviki ele alınan 11 ülkeden sadece Türkiye ve Hollanda'da uygulanmakta iken sosyal güvenlik katkı teşviki Türkiye, Hollanda, Fransa ve Rusya'da uygulanmaktadır. Hollanda'da 1994 yılında yürürlüğe girmiş olan gelir vergisi stopajı ve sosyal güvenlik katkı payı (işveren katkı pay1 \%18,47 iken işçi katk1 payı \%27,65'dir) teşvikleri, bir firmanın Ar-Ge faaliyetlerinde çalışan personel maaşlarına ödedikleri ücret vergilerinde ve sosyal güvenlik ödemelerinde indirim sağlamakta olup 2016 yılında ilk 350.000€ için \%32 (Hollanda'da Ar-Ge odaklı olarak kurulan beş yaşından küçük şirketler "technostarter" için ise \%40) ve aşan kısım için ise \%16 oranında indirim yapılmaktadır. Bu indirim hakkı her bir işveren için maksimum 14 Milyon€ ile sınırlandırılmıştır. Türkiye'de ise 5746 Sayılı Araştırma ve Geliştirme Faaliyetlerinin Desteklenmesi Hakkında Kanun ile düzenlenmiş ve 1 Nisan 2008 tarihinde yürürlüğe girmiş olan gelir vergisi stopajı teşviki uygulamasında, Ar-Ge ve destek personelinin çalışmaları karşıllı̆̆ında elde ettikleri ücretlerinin doktoralı olanlar için \%90'1, diğerleri için \%80'i gelir vergisinden müstesna edilmiştir. 2016 y1lında ise Ar-Ge ve destek personelleri ibaresine tasarım personeli de eklenerek bu personellerinde gelir vergisi desteğinden faydalanabileceği belirtilmiştir. Ayrıca personellerin eğitim seviyelerine göre belirlenen gelir vergisi stopaji teşviki oranında da değişikliğe gidilmiş olup yapılan değişiklikle birlikte Ar-Ge, tasarım ve destek personellerinin çalışmaları karşıllı̆ında elde ettikleri ücretleri üzerinden asgari geçim indirimi uygulandıktan sonra hesaplanan gelir vergisinin; doktoralı personeller ile yükseköğretim kurumlarının matematik, fizik, kimya ve biyoloji lisans programlarından yüksek lisans mezunu olanlar için \%95'i, yüksek lisans eğitimine devam edenler ile yükseköğretim kurumlarının temel bilimler lisans programlarından lisans mezunu olanlar için \%90’1 ve lisans öğrencisi ve altında eğitim derecelerine sahip diğer personeller için \%80'i verilecek muhtasar beyanname üzerinden tahakkuk eden vergiden indirilmek üzere terkin edilmektedir.

Türkiye'de uygulanan sosyal güvenlik katkı payı teşvikinde ise, Ar-Ge faaliyetinde çalışan personellerin sigorta primi işveren hissesinin yarısı (sigorta primi işveren hissesi 5 puanlık indirim dikkate alınmadığında teşvik oranı $\% 10,25$ 'dir) her bir çalışan için Maliye Bakanlığı bütçesine konulacak ödenekten karşılanmaktadır. Fransa ve Rusya' da ise sadece sosyal güvenlik katkı payı (işveren payı \%50, işçi payı \%30) teşviki uygulanmakta olup Fransa'da Ar-Ge çalışanlarının 
sosyal güvenlik katkı paylarının \%30'u vergi kredisi şeklinde sağlanmakta ayrıca genç yenilikçi şirketler 7 yıl boyunca belirli şartlar altında sosyal güvenlik katkı paylarından muaf kılınmışken Rusya'da ise \%30 olan sosyal güvenlik katkı payı, Ar-Ge çalışanları için \%14 olarak indirimli şekilde uygulanmaktadır. Ar-Ge faaliyetleri kapsamında ülkelerde uygulanan gelir vergisi stopaj ve sosyal güvenlik katkı payı teşvikleri Şekil 1'de özetlenmiştir.

Şekil 1: Türkiye ve Seçilmiş Ülkelerde Gelir Vergisi Stopajı ve Sosyal Güvenlik Katkı Payı Teşviki

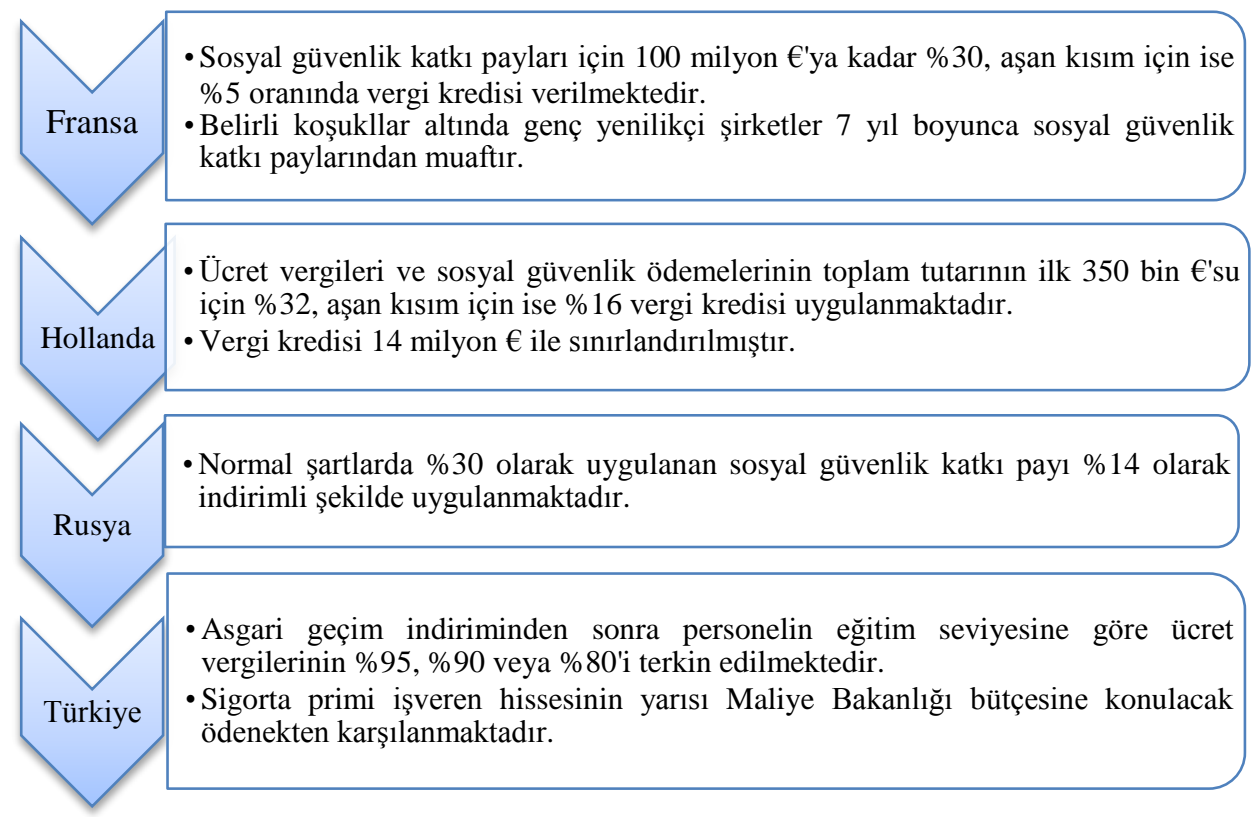

Kaynak: Yazarlar tarafindan oluşturulmuştur

Şekildeki bilgiler 1şığında gelir vergisi stopaj uygulaması bakımından Türkiye'nin Hollanda'ya göre daha büyük bir oranda teşvik sunduğunu, sosyal güvenlik katkı payı ödemeleri açısından ise Fransa'nın diğer ülkelere göre daha cömert bir teşvik sunduğu söylenebilir.

\section{Vergi Tatili Açısından Karşılaştırma}

Vergi tatili uygulaması genel olarak belirli zaman periyotlarında kurumlar vergisi, katma değer vergisi, mülk ve arazi vergisi vb. vergilerde indirim veya muafiyet şeklinde işlemekte olup çoğunlukla yeni kurulmuş teknolojik firmalara yönelik uygulanmaktadır. Bu teşvikin uygulanmasındaki amaç Ar-Ge faaliyetleri genellikle uzun bir emek gerektirdiğinden firmaların kâr elde etmesi birkaç yıl sonra gerçekleşebilmektedir. Bundan dolayı bu firmaların üzerindeki vergi yükü kaldırılarak veya azaltılarak yenilik faaliyetlerinin sürdürülebilirliği sağlanmak istenmektedir. Seçilmiş ülkelerden Fransa, Çin ve Rusya'da vergi tatili teşviki uygulanmakta olup bunların karşılaştırılması Şekil 2'de gösterilmiştir. Vergi tatili açısından ülkeleri karşılaştırdığımızda en fazla teşvik sırasıyla Çin, Rusya ve 
Fransa' da uygulanmaktadır. Çin ve Rusya'da üst sınır yokken Fransa'da vergi tatili süresi boyunca faydalanılacak belirli bir üst sınır belirlenmiştir. Çin'de farklı proje ve endüstriler için farklı vergi tatilleri uygulanmış olup en kısa periyod $2+3$ yıl en uzun periyod ise $5+5$ yıl olarak belirlenmiştir.

Şekil 2: Seçilmiş Ülkelerde Vergi Tatili Uygulaması

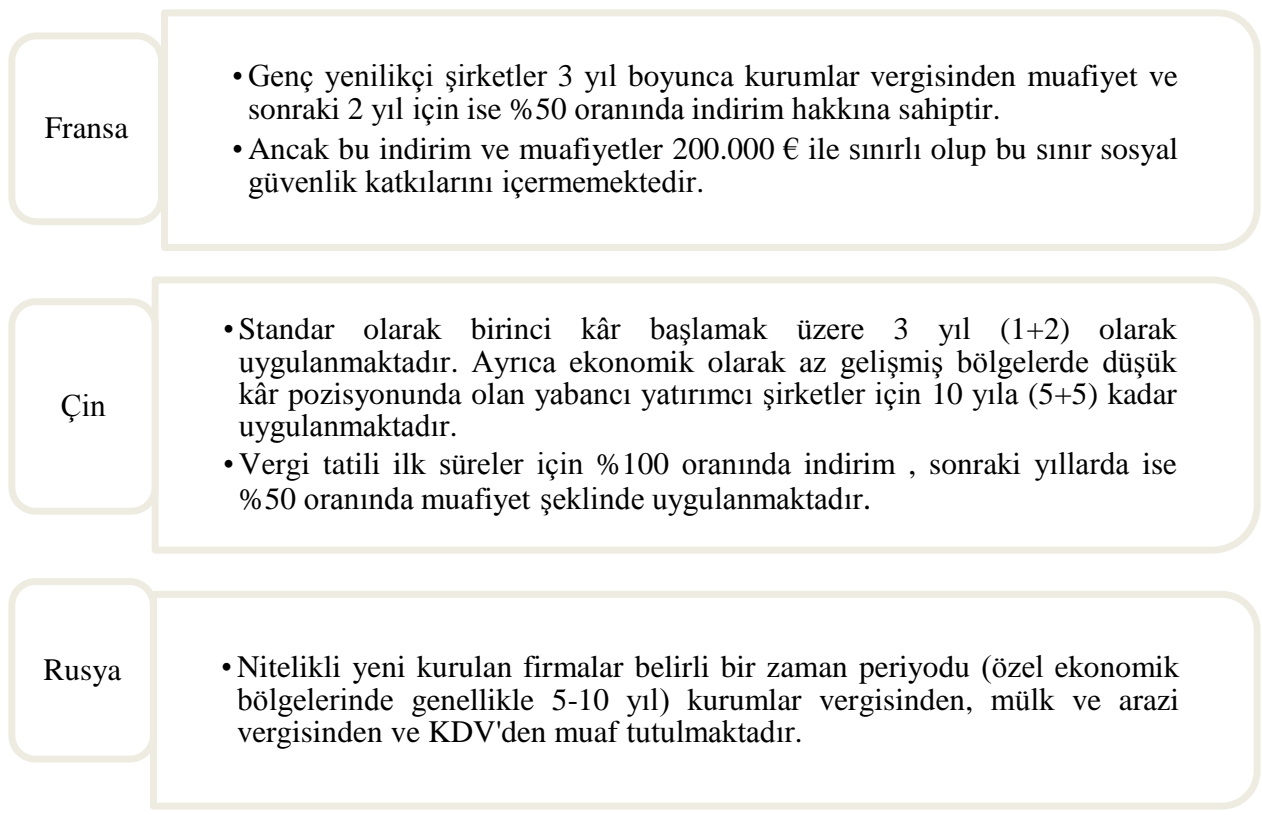

Kaynak: Yazarlar tarafindan oluşturulmuştur

\section{E. İndirimli Vergi Oranı ve Muafiyet Açısından Karşılaştırma}

Seçilmiş ülkelerden Çin ve Rusya Ar-Ge faaliyetleri için hem indirilmiş kurumlar vergisi oranı hem de muafiyet teşvikini uygulamıştır. Fransa ve Hollanda bu teşviklerden sadece indirilmiş kurumlar vergisi oranını, İspanya ve Türkiye ise sadece muafiyet sunmuşken diğer ülkelerde bu teşvik araçlarından herhangi biri uygulanmamıştır. İndirilmiş kurumlar vergisi oranı $(\mathrm{KVO})$ veya vergi muafiyeti teşvikleri, üretim tesislerinin yer seçiminde önemli bir araç olarak kullanılmakta olup ülkelerde bu teşvik araçlarının nasıl uygulandığı Tablo 4'te açıklanmıştır. Ülkeleri indirilmiş kurumlar vergisi oranı açısından karşılaştırdığımızda en fazla indirimi Hollanda'nın (\%20), en az indirimi ise özel ekonomik bölgeler haricinde Rusya'nın $(\% 4,5)$ yaptığı görülmektedir. Diğer ülkelerden Fransa \%18,33 oranında bir indirim uygulamışken, Çin ise \%10 oranında indirim sağlamıştır. Rusya genel olarak \% 4,5 indirimli oran uygulayarak son sirada yer alsa da özel ekonomik bölgelerine $\% 20$ oranında indirim sağlayarak, kurumlar vergisi oranını \%0'a indirgemiş olmakta ve böylece en fazla teşviki de sağlamış olmaktadır.

Diğer bir teşvik aracı olan muafiyet açısından ülkeleri karşılaştırdığımızda ise Rusya'da eş değeri üretilmeyen ekipmanlara yönelik ithalatta KDV ve gümrük vergisi muafiyeti ile enerji tasarruflu varlıklar için emlak vergisi muafiyeti 
geçerlidir. İspanya'da işletmeler, bazı maddi olmayan varlıklarından elde ettikleri gelirlerinden dolayı $\% 60$ oranında kurumlar vergisinden muaf tutulmuştur. Türkiye'de Ar-Ge ve inovasyon faaliyetleriyle ilgili düzenlenen belgeler damga vergisinden muafken teknoloji geliştirme bölgelerindeki yönetici şirketler de düzenlenen kâğıtlardan ve yapılan işlemlerden dolayı damga vergisi ve harçtan muaftır. Çin'de ise KDV ve gümrük vergisi muafiyetine ilaveten teknoloji ve yazılım şirketleri ilk 5 Milyon Yuan gelirlerinden dolayı kurumlar vergisinden muaf olmuşlardır.

Tablo 4: Türkiye ve Seçilmiş Ülkelerde İndirimli Kurumlar Vergisi Oranı ve Vergi Muafiyeti Teşvikleri

\begin{tabular}{|c|c|c|}
\hline \multicolumn{2}{|c|}{$\begin{array}{l}\text { Ülkeler ve } \\
\text { Teşvikler }\end{array}$} & Açıklama \\
\hline 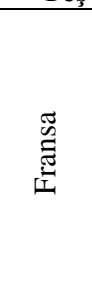 & 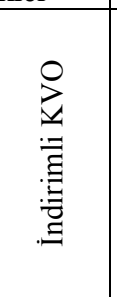 & $\begin{array}{l}\text { Patentler, patentli buluşlar ve patent ve patentli buluşlar için vazgeçilmez bir } \\
\text { unsur olarak görülen ve ilgili patent veya patentli buluş ile birlikte } \\
\text { ruhsatlandırılan endüstriyel/imalat süreçlerinden elde edilen gelirler, belirli } \\
\text { şartlara tabi olmak kaydıyla (sabit bir varlık olarak nitelenen maddi olmayan } \\
\text { duran varlık olması veya } 2 \text { yıl elde tutulmuş olması gerekir. Lisans ve satıcı } \\
\text { şirketlerin Ar-Ge faaliyetlerinden kaynaklanan fikri mülkiyet hakları için } \\
\text { asgari elde tutma süresi yoktur) \%33,33 olan kurumlar vergisi oranı yerine } \\
\% 15 \text { indirimli orana tabidir. }\end{array}$ \\
\hline \multirow[b]{2}{*}{$\exists$} & 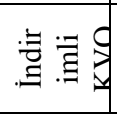 & $\begin{array}{l}\text { Faaliyetleri } \mathrm{Ar}-\mathrm{Ge} \text { olan yeni ileri/yüksek teknolojik işletmeler için kurumlar } \\
\text { vergisi oranı \%25 yerine } \% 10 \text { indirimli olarak } \% 15 \text { şeklinde } \\
\text { uygulanmaktadır. }\end{array}$ \\
\hline & 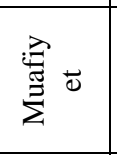 & $\begin{array}{l}\text { Nitelikli teknoloji transferleri için katma değer ve gümrük vergisi muafiyeti } \\
\text { uygulanmaktadır. Ayrıca teknoloji ve yazılım işletmeleri, elde ettiği ilk } 5 \\
\text { Milyon Yuan karşılloğında kurumlar vergisinden muaf olup aşan kısım için } \\
\text { kurumlar vergisinin yarısından muaftırlar. }\end{array}$ \\
\hline 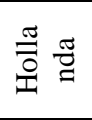 & 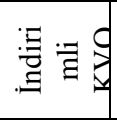 & $\begin{array}{l}\text { Yenilikçi işletmelerin kendi geliştirdiği maddi olmayan varlıklardan elde } \\
\text { edilen gelirler için } \% 25 \text { kanuni vergi oranı yerine } \% 5 \text { tercihli efektif vergi } \\
\text { oranı uygulanmaktadır. }\end{array}$ \\
\hline 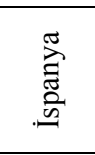 & 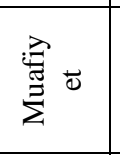 & $\begin{array}{l}\text { İspanya'da kısmi vergi muafiyeti geçerlidir. Firmalar bazı maddi olmayan } \\
\text { varlıkların (patent, çizim, model, teknik bilgi vb.) lisanslanmasından ve } \\
\text { devredilmesinden elde edilen net gelirler karşılığında \%60 oranında } \\
\text { kurumlar vergisinden muaftır. }\end{array}$ \\
\hline \multirow[t]{2}{*}{ 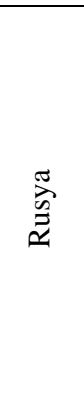 } & 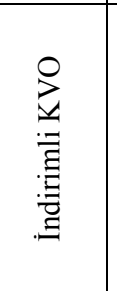 & $\begin{array}{l}\text { Rusya'da bazı bölgelerde teknolojik ve inovasyon faaliyetlerinde kullanılan } \\
\text { varlıklara yönelik olarak ilk } 5 \text { yıl için mülk ve arazi vergisi istisna şeklinde } \\
\text { uygulanmışken sonraki } 5 \text { yıl için ise } \% 50 \text { indirimli şekilde uygulanmıştır. } \\
\text { Ayrıca projeleri, bölgesel işletme öncelikleriyle uyumlu olan ve bölgesel } \\
\text { kanun ile belirlenen minimum yatırımı gerçekleştiren firmalar için kurumlar } \\
\text { vergisi oranı } \% 4,5 \text { indirimli şekilde } \% 15,5 \text { olarak uygulanmaktadır. Bazı } \\
\text { ekonomik bölgelerde ise özel vergi rejimi kapsamında indirilmiş kurumlar } \\
\text { vergisi oran } \% 0 \text { olarak uygulanmaktadır }\end{array}$ \\
\hline & $\stackrel{\overparen{\Xi}}{\stackrel{\varpi}{\Sigma} . ~}$ & $\begin{array}{l}\text { Rusya'da üretilen eş değer olmayan teknolojik ekipmanlara yönelik ithalatta } \\
\text { KDV ve gümrük vergisi muafiyeti mevcuttur. Ayrıca enerji tasarruflu } \\
\text { varlıklar için } 3 \text { yıl emlak vergisi muafiyeti vardır. }\end{array}$ \\
\hline 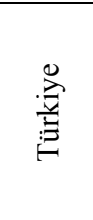 & 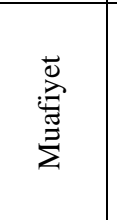 & $\begin{array}{l}\text { Ar-Ge ve inovasyon faaliyetleriyle (bir Ar-Ge personeline yapılan ücret } \\
\text { ödemeleri için düzenlenen belgeler de dâhil olmak üzere) düzenlenen bir dizi } \\
\text { belge (sözleşmeler ve bordro fişleri) damga vergisinden muaftır. Ayrıca } \\
\text { teknoloji geliştirme bölgelerindeki yönetici şirketler de kanunu } \\
\text { uygulanması ile ilgili olarak düzenlenen kâğıtlardan ve yapılan işlemlerden } \\
\text { dolayı da damga vergisi ve harçtan muaftır. }\end{array}$ \\
\hline
\end{tabular}


Kaynak: Yazarlar tarafindan oluşturulmuştur.

\section{F. Patent Kutusu Rejimi Açısından Karşılaştırma}

Patent haklarının veya patentlerin satışından veya lisanslanmasından elde edilen kazançlar için indirimli kurumlar vergisi oranı teşviki uygulanmakta olup bu teşviki İngiltere, Fransa, İspanya ve Hollanda sunmaktadır. Bu ülkelerdeki firmaların patent kutusu rejimi kapsamında belirli bir kazanç elde ettiği varsayımından hareketle uygulanan teşvikin ülke bazında firmalara ne kadarlık bir vergi avantajı sağladığı, normal kurumlar vergisi ve indirilmiş kurumlar vergisi oranının kazanca uygulanması şeklinde hesaplanmaktadır. İngiltere'de bu teşvikin hesaplanması diğer ülkelere nazaran biraz değişiklik göstermektedir. Diğer ülkelerde paten kutusu rejimi kapsamında elde edilen kazanca direk indirilmiş oran uygulanırken, İngiltere'de normal kurumlar vergisi ile indirilmiş kurumlar vergisi oranı arasındaki farkın normal kurumlar vergisi oranına bölünmesi sonucu çıkan değer kazanca uygulanmaktadır. Bu ülkelerdeki firmaların paten lisanslanması sonucunda 5.000€ kazanç elde ettiği varsayımından hareketle, ülkelerin ne kadar büyüklükte vergisel avantaj sunduğu Grafik 1'de gösterilmiştir.

Grafik 1: Seçilmiş Ülkelerde Paten Kutusu Rejimi Teşvikinin Sağladığı Vergi Avantaj1

\begin{tabular}{|c|}
\hline Vergi Avantaj1 \\
Ispanya; $750 €$ \\
$24 \%$ \\
\\
Vergi Avantaj1 \\
Hollanda; \\
$1000 €$ \\
$32 \%$
\end{tabular}

Kaynak: Yazarlar tarafindan oluşturulmuştur.

Grafik 1'deki ülkelerden Hollanda'da indirimli kurumlar vergisi oran1 \%5, İspanya'da \%10, Fransa'da \%15 ve İngiltere'de \%4,7 olarak uygulanmaktadır. ${ }^{11}$ Ülkeleri patent kutusu rejimi teşviki bakımından sıraladığımızda en fazla teşviki sırasıyla Hollanda, Fransa, İspanya ve İngiltere sağlamaktadır. Şekildeki oranlar toplam vergi avantajı içerisinde ülkelerin sağlamış olduğu vergi avantaj oranlarını göstermektedir.

\section{G. Türkiye ve Seçilmiş Ülkelerde Ar-Ge Vergi Teşvik Araçlarının Siralaması}

Türkiye ve seçilmiş ülkelerde Ar-Ge faaliyetleri için sunulan teşvik araçları Tablo 5'de ele alınmıştır. Ar-Ge indirimi sıralamasında sağlanan teşvik miktarı,

\footnotetext{
${ }^{11}$ Ülkelerdeki normal kurumlar vergisi oranı 1 Nisan 2017'den itibaren Hollanda'da \%25, Fransa'da \%33,33, İngiltere'de \%19 ve İspanya'da \%25'dir.
} 
vergi kredisi sıralamasında kurumlar vergisi oranında meydana gelen azalma ve verilen kredi miktarı, gelir vergisi stopaj sıralamasında teşvik oranı, sosyal güvenlik katkı payı sıralamasında uygulanan kredi oranı ve indirilmiş sosyal güvenlik katkı oranları, vergi tatili sıralamasında tatil periyotları, indirilmiş kurumlar vergisi sıralamasında ise ne kadarlık bir vergi indirim oranı uygulandığı ve patent kutusu rejiminde ne kadarlık bir vergi avantajı sağlandığı dikkate alınmıştır.

Ülkelerin daha cömert Ar-Ge faaliyetlerinin gerçekleştirilmesi için sunmuş oldukları teşvik araçları sıralamasına baktığımızda özellikle Fransa ve Hollanda'nın neredeyse bütün teşvik araçlarını sunduğunu ve üst sıralarda yer aldığını görmekteyiz. Çin'de Ar-Ge faaliyetleri için üç teşvik aracı sağlanmakta olup bu teşviklerden vergi tatili kapsamında diğer ülkelerden daha cömert iken ArGe indirimi bakımından ise Hollanda'dan sonra ikinci sırada yer almaktadır. Uyguladığı teşvik araçları bakımından en az etkili olduğu teşvik aracı ise indirimli kurumlar vergisi uygulamasıdır. İngiltere, Avusturya ve Türkiye diğer ülkelere göre daha az teşvik aracı sunmakta ve sundukları teşvik araçlarının etkisi bakımından da son sıralarda yer almakta iken bu ülkelerden sadece Türkiye gelir vergisi stopaj uygulaması açısından önemli bir yere sahiptir.

Tablo 5: Türkiye ve Seçilmiş Ülkelerde Ar-Ge Vergi Teşvik Araçları

\begin{tabular}{|c|c|c|c|c|c|c|c|}
\hline Z & $\begin{array}{c}\text { Ar-Ge } \\
\text { İndirimi }\end{array}$ & $\begin{array}{c}\text { Vergi } \\
\text { Kredisi }\end{array}$ & $\begin{array}{c}\text { Gelir } \\
\text { Vergisi } \\
\text { Stopaj1 }\end{array}$ & $\begin{array}{c}\text { Sosyal } \\
\text { Güvenlik } \\
\text { Katk1 } \\
\text { Pay1 }\end{array}$ & $\begin{array}{c}\text { Vergi } \\
\text { Tatili }\end{array}$ & $\begin{array}{c}\text { İndirimli } \\
\text { Oran }\end{array}$ & $\begin{array}{c}\text { Patent } \\
\text { Kutusu } \\
\text { Rejimi }\end{array}$ \\
\hline 1 & Hollanda & İspanya & Türkiye & Fransa & Çin & Hollanda & Hollanda \\
\hline 2 & Çin & Danimarka & Hollanda & Hollanda & Rusya & Fransa & Fransa \\
\hline 3 & ABD & Fransa & --- & Rusya & Fransa & Rusya & İspanya \\
\hline 4 & Fransa & Rusya/ABD & --- & Türkiye & --- & Çin & İngiltere \\
\hline 5 & Rusya & Hollanda & --- & --- & --- & --- & --- \\
\hline 6 & Danimarka & Kanada & --- & --- & --- & --- & --- \\
\hline 7 & İngiltere & Avusturya & --- & --- & --- & --- & --- \\
\hline 8 & Türkiye & İngiltere & --- & --- & --- & --- & --- \\
\hline 9 & Avusturya & --- & --- & --- & --- & --- & --- \\
\hline
\end{tabular}

Kaynak: Yazarlar tarafindan oluşturulmuştur.

\section{SONUÇ}

Türkiye'de her yeni kanun ile Ar-Ge faaliyetleri daha fazla teşvik edilmeye çalışılmış ve Ar-Ge merkezi kurulabilmesi için gerekli olan kriterler yumuşatılmış ancak sosyal getirisi özel getirisinden fazla olan Ar-Ge yatırımları istenilen düzeye ulaşamamıştır. Sosyal getirisi özel getirisinden daha fazla gerçekleşen Ar-Ge yatırımları konusunda firmaların çekingen davranmasının önüne geçmek için İspanya, İngiltere, Hollanda ve Fransa ülkelerinde patent kutusu rejimi uygulanmaktadır. Bu teşvik fikri mülkiyet haklarını koruyan kanuni bir düzenleme olup yapılan bir buluşun, kısa sürede diğer firmalar tarafindan taklit edilmesinin önüne geçmekte ve buluşu gerçekleştiren firmanın belirli bir dönem boyunca kârlılığını artırmaktadır. Hatta bu teşvik uygulaması firmaların vergi yükünü de azaltmaktadır. Zira patent haklarının veya patentlerin satışından veya 
lisanslanmasından elde edilen kazançlar için indirimli kurumlar vergisi oranı uygulanmaktadır. Türkiye'de ise fikri mülkiyet haklarını koruyucu yeterli kanuni düzenlemenin olmaması ve yapılan bir buluşun, kısa sürede diğer firmalar tarafından taklit edilerek yayılması, buluşu gerçekleştiren firmanın kârlılığını düşürmekte buda $\mathrm{Ar}-\mathrm{Ge}$ faaliyetlerinin gerçekleştirilmesinin önünde bir engel teşkil etmektedir. Bunun için Türkiye'nin de diğer ülkelerde uygulandığı gibi paten hakları için indirimli kurumlar vergi oranı uygulayarak bu faaliyetleri teşvik etmesi gerekmektedir.

Ar-Ge ve inovasyon faaliyetlerinin gerçekleştirilmesinde birçok ülke tarafindan firmalara yönelik vergi kredisi teşviki de uygulanmakta iken Türkiye'de bu teşvik uygulamasına yer verilmemiştir. Bu teşvik uygulaması sadece büyük firmalara sağlanmamakta aynı zamanda Ar-Ge faaliyetlerinin tabana yayılabilmesi ve Ar-Ge kültürünün oluşabilmesi için küçük ve orta ölçekli firmalara yönelik olarak da uygulanmaktadır. Hatta likidite kısıtlı küçük ve orta ölçekli firmalara daha büyük oranlarda vergi kredisi teşviki sağlanmakta olup bu şirketlerin ödenecek kurumlar vergisi miktarı azaltılmaktadır. Ar-Ge faaliyetleri kapsamında sağlanan teşviklerden vergi kredisi uygulamasının, genellikle finansman elde etmek için daha büyük engellerle karşı karşıya kalan genç firmalara ek destek sağlanması yönünden en iyi uygulama olduğu da kabul edilmektedir. Çünkü negatif vergi, Ar-Ge faaliyetleri henüz gelir getirmediğinde, bu küçük firmaların başlangıç aşamasındaki likiditesini güçlendirmektedir. Türkiye'de ise işletmelerin yaklaşık \%98'ini likidite kısıtlı mikro, küçük ve orta ölçekli firmaların oluşturduğu göz önünde bulundurulduğunda bu teşvik aracının Türkiye için ne kadar önemli olduğu anlaşılmaktadır. Çünkü başlangıç aşamasında likidite sorunu yaşayan firmaların yüksek bir maliyet ve uzun bir dönem gerektiren Ar-Ge faaliyetlerini gerçekleştirmesi imkânsızdır. Bu açıdan Ar-Ge faaliyetlerinin genişletilmesi ve ArGe kültürünün oluşturulabilmesi için Türkiye'de de vergi kredisi teşvikinin uygulanması ve firmaların Ar-Ge faaliyetlerine cesaretlendirilmesi gerekmektedir. Diğer ülkelerde uygulanıp ta Türkiye'de belirli bir oranda uygulanmak ta olan ArGe indiriminin de süper Ar-Ge indirim şekline dönüştürülmesi gerekmektedir. Yani Ar-Ge indirim oranının \%100'ün üzerine çıkartılması gerekmektedir. Bu teşviki uygularken bütün firmalar için değil de belirli bir dönem ortalaması (2012-2016 vb. dönem ortalaması) Ar-Ge harcamalarını aşan firmalar için geçerli olacağ 1 kriteri koyulmalı veya Ar-Ge indirimi matrah yerine vergiden indirim olarak düzenlenip, bazı ülkelerde olduğu gibi zarar ve benzeri sebeplerle vergi çıkmaması durumunda iade öngörülebilir.

Sonuç olarak Ar-Ge kavramının Türkiye'de ilerlemesi için bir sistematiğin oluşturması ve bu sistematiğin Ar-Ge kültürü olarak firmalara aşılanması gerekmektedir. Çünkü Türkiye'de hâlâ Ar-Ge kültürü oluşturulamamıştır. Nitekim büyük ve vizyon sahibi şirketler Ar-Ge'nin önemini bilirken, küçük ve orta ölçekli şirketlere de bunun yayılması gerekmekte olup 2023 hedeflerinin gerçekleştirilebilmesi için bu bir elzemdir. Zira Türkiye'de Ar-Ge faaliyetlerinin gerçekleştirildiği büyük şirketlerin oranı sadece \%2'yi teşkil etmekte, geriye kalan 
\%98'lik kısmın bütçesi kısıtlı bulunmakta olup bu firmaların; maliyetlerin düşürüldüğü ve verimliliğin artırılabildiği küresel pazarda kendisini kanttlayabilmesi için yeni ve katma değeri yüksek ürünler, sistemler, süreçler ve teknolojiler geliştirmeleri, bunları gerçekleştirebilmek için de Ar-Ge faaliyetleri yapmak zorunda olduklarının kavranması gerekmektedir. Ar-Ge harcamaları sonunda elde edilen yeni ve katma değeri yüksek ürün, sistem, süreç ve teknolojilerde yüksek maliyet ve uzun bir zaman gerektirdiği ve sonuçlarının elde edilememe olasılığı da olduğu hatta sosyal getirisi de özel getirisinden fazla gerçekleştiği için bu faaliyetlerin devlet tarafindan desteklenmesi gerekmektedir.

\section{KAYNAKÇA}

Baştürk, K. (2012). Vergi Teşvik Politikası ve Türkiye'de Ar-Ge Faaliyetlerine Yönelik Vergi Teşvikleri, (Basılmamış Yüksek Lisans Tezi), Selçuk Üniversitesi Sosyal Bilimler Enstitüsü, Konya.

Bezirci, M. (2012). Ar-Ge Teşvikleri, 1. Baskı, Beta Basım Yayım Dağıtım A.Ş., İstanbul.

Bilim ve Teknoloji Genel Müdürlüğü (2017). Teknoloji Gelistirme Bölgeleri, https://teknopark.sanayi.gov.tr/Upload/SingleFile/Dosya-461-826.pdf, (07.08.2017).

Can, F. (2007). Dünyada ve Türkiye'de Araştırma Geliştirme Faaliyetlerine Yönelik Vergisel Teşvikler, (Basılmamış Yüksek Lisans Tezi), KTÜ SBE, Trabzon.

Çürük, T. ve Türk, Z. (2004). Araştırma ve Geliştirme Faaliyetleri, Türkiye'deki Düzenlemeler ve Muhasebe Uygulamaları, Nobel Kitapevi, İzmir.

Demirli, Y. (2015). "Türk Vergi Sisteminde Ücret Tabanlı İstihdam Teşvikleri: Gelir Vergisi Stopaj1 Teşviki/Desteği ve Ücret İstisnası”, Uluslararası Yönetim İktisat ve İşletme Dergisi, Cilt 11, Say1 25, 141-162. Doi:10.17130/ijmeb.2015.11.25.933.

Evci, C. (2004). Ar-Ge Vergi Teşvikleri, (Basılmamış Yüksek Lisans Tezi), Ankara Üniversitesi Sosyal Bilimler Enstitüsü, Ankara.

Köhler, C. vd. (2012). "The Impact and Effectiveness of Fiscal Incentives for R\&D”, Manchester Institute of Innovation Research, Nesta Working Paper No: 12/01. https://www.nesta.org.uk/sites/default/files/the_impact_and_effectiveness_of_fiscal_incentives. pdf

Mazars (2016). 5746 Sayılı Ar-Ge Faaliyetlerinin Destelenmesi Hakkında Kanun, 4691 Sayılı Teknoloji Geliştirme Bölgeleri Kanunu ve Bazı Vergi Kanunlarında Ar-Ge Faaliyetlerinin Desteklenmesine Yönelik Düzenlemeler İçeren 6676 Sayılı Kanun Yayınlanmıştı’”, Sirküler Sayı: 2016/052.

OECD (2017). OECD Review of National R\&D Tax Incentives and Estimates of R\&D Tax Subsidy Rates, TAX4INNO Project 674888.

Vural, İ. (2009). Yorum ve Açıklamalarla Kurumlar Vergisi Kanunu, Gelirler Kontrolörleri Derneği, İstanbul.

Yavuz, B. (2010). Ar-Ge Faaliyetlerine İlişkin Teşvikler ve Ar-Ge Giderlerinin UMS-TMS Kapsamında Mali Tablolara Yansıttlması, (Basılmamış Yüksek Lisans Tezi), Marmara Üniversitesi Sosyal Bilimler Enstitüsü, İstanbul.

6676 Sayılı Araştırma ve Geliştirme Faaliyetlerinin Desteklenmesi Hakkında Kanun ile Bazı Kanun ve Kanun Hükmünde Kararnamelerde Değişiklik Yapılmasına Dair Kanun, 12/3/2008 Tarih, 26814 Sayılı T.C. Resmi Gazete, http://www.mevzuat.gov.tr/MevzuatMetin/1.5.5746.pdf, (15,03.2016).

30111 sayılı Resmi Gazete (2017). "Sanayinin Geliştirilmesi ve Üretimin Desteklenmesi Amacıyla Bazı Kanun Ve Kanun Hükmünde Kararnamelerde Değişiklik Yapılmasına Dair Kanun”, http://www.resmigazete.gov.tr/eskiler/2017/07/20170701-21.htm (20.08.2017).

Araştrma ve Geliştirme Faaliyetlerinin Desteklenmesine İlişkin Uygulama ve Denetim Yönetmeliği, 31/07/2008 Tarih, 26953 Sayll T.C. Resmi Gazete http://www.resmigazete.gov.tr/eskiler/2008/07/20080731-2.htm (10.03.2016).

5746 Sayılı Araştırma ve Geliştirme Faaliyetlerinin Desteklenmesi Hakkında Kanun; 28/2/2008 Tarih, 26814 Sayll T.C. Resmi Gazete http://www.resmigazete.gov.tr/eskiler/2008/03/20080312-2.htm (03.02.2016). 


\section{SUMMARY}

All of Turkey and selected countries offer various incentives for R\&D activities and these incentives are essential for the realization of R\&D activities. Because R\&D activities (look like walking in a dark space whose end is invisible) are at a high risk and the return can be partially achieved in the long run. That is, the difficulties that the investor investing in $R \& D$ activities can cost itself $R \& D$ results; the market failures created by the indivisibility of the $R \& D$ and innovation process and the inadequacy of $\mathrm{R} \& \mathrm{D}$ investments for the development of new technologies in free market conditions make it impossible for the R\&D activities to be achieved by the private sector on appropriate terms and at all times. Therefore, many countries directly or indirectly support private sector R\&D activities through various incentive mechanisms in order to increase the levels of technology and innovation and to strengthen international competitiveness levels.

In order to prevent companies from being hesitant about R\&D investments that are realized more than the social effect special effect, the patent system regime is applied in Spain, England, Netherlands and France countries and the fact that there is not sufficient legislative regulation to protect the intellectual property rights in Turkey, imitating and spreading by firms, reduces the profitability of the company that realizes the invention, which is an obstacle to the realization of R\&D activities. In the realization of $R \& D$ and innovation activities, many countries implement the tax credit incentive for the firm while this incentive application has not been included in Turkey. With this incentive, small and medium-sized firms with limited liquidity are provided with tax credits at a greater rate and the amount of corporation tax to be paid to these companies is reduced. It is also acknowledged that the application of the tax credit from incentives provided under R\&D activities is the best practice for providing additional support to the younger firm, which is usually faced with greater obstacles to obtaining financing. Because the negative tax strengthens the liquidity of the initial stages of small firms when R\&D activities do not bring in income yet. The majority of enterprises in Turkey; small and medium-sized firms with liquidity constraints, it is understood how important this incentive instrument is for Turkey. Because companies with liquidity problems in the initial stages are unable to carry out research and development activities that require a high cost and a long period of time. In this respect, in order to expand R\&D activities and create R\&D cults, Turkey should also be encouraged to apply the tax credit incentive and companies' R\&D activities. The R\&D offer which is applied in other countries and applied in a certain place in Turkey needs to be transformed into a super R\&D discount plan. 